\title{
Crude Oil Contamination Enhances the Lipoxygenase Gene Expression in the Green Microalga Scenedesmus dimorphus
}

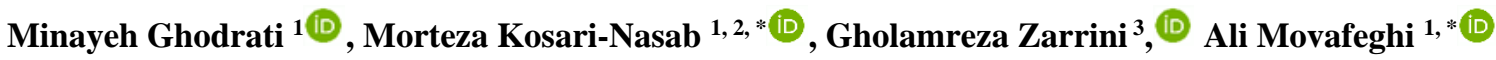 \\ 1 Department of Plant Sciences, Faculty of Natural Sciences, University of Tabriz, Tabriz, Iran; movafeghi@tabrizu.ac.ir \\ (A.M.); \\ 2 Drug Applied Research Center, Tabriz University of Medical Sciences, Tabriz, Iran; mortazakosari56@ gmail.com (M.K.); \\ 3 Department of Animal Biology, Faculty of Natural Sciences, University of Tabriz, Tabriz, Iran; zarrini@tabrizu.ac.ir \\ (G.Z.); \\ * Correspondence: mortazakosari56@gmail.com (M.K.); movafeghi@ tabrizu.ac.ir (A.M.);
}

Scopus Author ID 6507587500

Received: 18.11.2020; Revised: 5.12.2020; Accepted: 7.12.2020; Published: 11.12.2020

\begin{abstract}
Crude oil is a mixture of hydrocarbons, which are mainly toxic to living organisms. Over recent years it has become clear that algae may play a substantial role in the biodegradation of the crude oil harmful hydrocarbons by their dioxygenase system. The present study was conducted to evaluate alterations in the expression levels of lipoxygenase gene (lox) in Scenedesmus dimorphus after exposure to crude oil. The extraction of total RNA was performed by RNX plus reagent. After cDNA synthesis, a qRT-PCR analysis was performed to determine the expression level of the lox gene. The acquired data were analyzed by SPSS Statistics. Based on the obtained results, crude oil treatments $(0.02$ and $1 \%$ ) led to a relatively high expression level of lox compared to control conditions. Moreover, incubation time significantly affected the relative expression of this gene in both oil-treated and nontreated algae. The outcomes of this research indicated that $S$. dimorphus has a high potential for the enhancement of enzymatic activity under crude oil treatment through increased lox expression.
\end{abstract}

Keywords: biodegradation; crude oil contamination; lipoxygenase; Scenedesmus dimorphus.

(C) 2020 by the authors. This article is an open-access article distributed under the terms and conditions of the Creative Commons Attribution (CC BY) license (https://creativecommons.org/licenses/by/4.0/).

\section{Introduction}

Over the past few years, the contamination of aquatic ecosystems with hydrocarbonrich crude oil has attracted a great deal of attention. Under the sunlight, polycyclic aromatic hydrocarbons (PAHs) might be converted to diverse oxidant compounds and eventually to oxygen $\left({ }^{1} \mathrm{O}_{2}\right)$, alkoxyl $\left(\mathrm{RO}^{*}\right)$, and hydroxyl $\left(\mathrm{OH}^{*}\right)$ radicals [1,2]. These radicals damage macromolecules and inhibit cell growth and development [2]. Hence, microbial decomposition of PAHs could be considered as an essential environmental process. Some microorganisms such as bacteria, algae, and fungi can partially or entirely metabolize the toxic PAHs through different metabolic pathways [3-5]. Several bacteria and algae decompose PAHs and use the biodegradation products as carbon and energy sources [5-7]. Bacteria degrade PAHs by two different pathways depending on the presence or absence of oxygen. The aerobic bacterial degradation of PAHs is carried out through oxygenase-mediated reactions. Accordingly, monooxygenase or dioxygenase enzymes decay the aromatic ring through ortho-cleavage or meta-cleavage pathways and produce diol intermediates that are ultimately converted to the tricarboxylic acid (TCA) cycle intermediates. The anaerobic degradation of PAHs relies on 
reductive reactions using the alternative electron acceptors such as nitrate, sulfate, or ferric ions via the cytochrome P450-mediated pathway [2,6]. In green algae, PAHs are degraded by the dioxygenase system. The oxygen needed to break a chemical bond is likely provided by photosynthesis $[5,8]$.

Members of lipoxygenase (LOX) enzymes, as a group of dioxygenase families, catalyze PAHs' oxidation by inserting two oxygen atoms into polyunsaturated hydrocarbons. They produce hydroperoxides that later become bioactive oxylipins (such as jasmonate), which are involved in numerous physiological procedures [9-11]. To date, many LOX-pathway-derived oxylipins have been identified in different algae that play substantial roles in signaling pathways and defense against biotic and abiotic stresses [12-15].

LOXs are encoded by a multigene family. They have a highly conserved amino acid sequence with two histidine residues crucial for metal (iron or manganese) binding and catalytic activity $[10,16]$. In plants and animals, these iron-containing enzymes encompass a small N-terminal domain PLAT/LH2 and a large C-terminal domain [10].

The substrate arrangement and its incorporation depth at the LOX enzyme's active site influence the pentadiene system's selection and the appropriate $\mathrm{C}-\mathrm{H}$ bond breakdown [17]. Thereby, different hydroperoxides can be produced. For example, in higher plants, 9hydroperoxy octadecatrienoic acid (9-HpOTE) or 13-hydroperoxy octadecatrienoic acid (13HpOTE) are formed as a result of the addition of oxygen to C-9 or C-13 of the hydrocarbons [18]. In mammals, oxygenation of hydrocarbons may take place at six different positions, including C-5, C-8, C-9, C-11, C-12, or C-15 by LOXs. Based on former studies, it seems likely that algae contain not only 5-, 8-, 9-, 12-, and 15-LOXs catalyzing eicosanoic (C20) polyunsaturated fatty acids (PUFAs), but also $\omega 3-, \omega 6-, \omega 9-$, and $\omega 10-L O X s$ catalyzing octadecanoids (C18) [18].

Although there are several reports on PAHs' biodegradation by algae [3,19-21], the molecular mechanisms of reactions and precise function of degradation enzymes have not been completely characterized. In the current study, the lox gene expression in the green microalga $S$. dimorphus has been investigated under different crude oil concentrations over the treatment time. This study's findings may provide new insights into the crude oil components' breakdown mechanism by the LOX system.

\section{Materials and Methods}

\subsection{Materials.}

Scenedesmus dimorphus samples were was gained from the Kavoshgaran Tabiat Pak Corporation in Rasht, Iran. The required crude oil was provided by Tabriz Oil Refinery.

\subsection{Culture condition.}

Algal cells were grown in $\mathrm{BG} 11$ medium at $25 \pm 1^{\circ} \mathrm{C}$, under an illumination intensity of 2000 lux, with a $12 \mathrm{~h} / 12 \mathrm{~h}$ light/dark cycle. After two days of culture, algal cells with an intensity of $2.3 \times 10^{5}$ cells $/ \mathrm{ml}$ were exposed to different crude oil concentrations $(0,0.02$, and $1 \% \mathrm{v} / \mathrm{v})$ for 21 days. The cells were gathered on 0 ( $2 \mathrm{~h}$ after treatment $), 7^{\text {th }}, 14^{\text {th }}$, and $21^{\text {st }}$ incubation days for experimental analyses. 


\subsection{Total RNA extraction and cDNA synthesis.}

S. dimorphus cells $(0.1 \mathrm{~g})$ were ground in liquid nitrogen and homogenized with RNX plus solution. The total RNA content was measured at $260 \mathrm{~nm}$ using a NanoDrop and reported as $\mu \mathrm{g} / \mathrm{g}$ FW. The purity of the extracted RNA was determined at ratios of $\mathrm{A}_{260} / \mathrm{A}_{280}$ and $\mathrm{A}_{260} / \mathrm{A}_{230}$. RNA quality was verified by electrophoresis using a 2\% agarose gel.

Single-stranded cDNA was synthesized using the RevertAid RT reagent kit (ThermoFisher Scientific). Accordingly, $3 \mu$ l of total RNA was mixed with random hexamer primer and nuclease-free water. The mixture was incubated in a thermocycler at $65{ }^{\circ} \mathrm{C}$ for 5 min. The samples were then treated with reaction buffer (5X), RNase inhibitor (40 unit/ $\mu$ l), dNTP $(10 \mathrm{mM})$, and RevertAid Reverse Transcriptase enzyme (200 unit/ $\mu \mathrm{l})$. Finally, the reaction mixture was incubated in the thermocycler at $25{ }^{\circ} \mathrm{C}$ for $10 \mathrm{~min}$ and $42{ }^{\circ} \mathrm{C}$ for one $\mathrm{h}$.

\subsection{Real-time quantitative PCR analysis.}

The design of primers for lox (target gene) and 18srRNA (internal reference gene) genes was performed according to the methods reported by Djian et al. [17] and Zhu et al. [18]. Analysis of the primers was performed by NCBI BLAST (Table 1). QRT-PCR was carried out on LightCycler ${ }^{\circledR} 96$ SW 1.1 Roche system using SYBR ${ }^{\circledR}$ PremixEx Taq ${ }^{\text {TM }}$ kit. The relative expression level of lox gene was calculated using the formula $2^{-\Delta \Delta C T}$. The cDNA-free negative control sample (No RT Control) was used to check the samples' genomic contamination. The size of the amplified product for the target gene was examined on a $2 \%$ agarose gel to ensure the primers' accuracy.

Table 1. The sequence of primers used in Real-Time PCR reaction.

\begin{tabular}{l|l|l|l} 
Gene & Forward primer & Reverse primer & \\
\hline Lox & $5^{\prime}$ GGCATCGGCGCGTGAGGCAG $^{3^{\prime}}$ & $5^{\prime}$ GACTACCCCTATGCAGCCGACG $^{3}$ & $84 \mathrm{bp}$ \\
\hline 18srRNA & ${ }^{5}$ AGTTAGGGGATCGAAGACGA ${ }^{3^{\prime}}$ & ${ }^{5}$ CAGCCTTGCGACCATACTC30 $^{3^{\prime}}$ & $153 \mathrm{bp}$
\end{tabular}

\subsection{Statistical analyses.}

A factorial experiment in a randomized complete block design with two replicates was carried out to investigate the effect of different levels of crude oil on the expression of lox gene. The obtained results were analyzed by 2-way ANOVA.

\section{Results and Discussion}

\subsection{Yield and quality of total RNA.}

Exposure of algae to crude oil resulted in higher RNA concentrations in the cells than the control samples. Furthermore, the RNA quantity in both control and oil-treated cells was significantly increased with the exposure time. The $\mathrm{A}_{260} / \mathrm{A}_{280}$ and $\mathrm{A}_{260} / \mathrm{A}_{230}$ ratios were higher than 1.8 in all samples, indicating the high purity of total RNA (Table 2). The presence of 28S and 18S rRNA bands on the agarose gel confirmed the RNA integrity and its optimal quality (Figure 1).

Table 2. Evalution of the quantity and quality of extracted RNA molecules.

\begin{tabular}{|c|c|c|c|}
\hline $\begin{array}{l}\text { Treatment } \\
\text { (Time, \% Crude oil) }\end{array}$ & $\begin{array}{l}\text { RNA yield } \\
(\mu \mathrm{g} / \mathrm{g} \text { FW })\end{array}$ & $\mathbf{A}_{260} / \mathbf{A}_{280}$ & $\mathbf{A} 260 / A_{230}$ \\
\hline Control & $0.74^{i}$ & 2.01 & 2.05 \\
\hline $7^{\text {th }}$ day & $0.963^{\mathrm{i}}$ & 2.005 & 1.99 \\
\hline $7^{\text {th }}$ day $+0.02 \%$ & $1.045^{\mathrm{h}}$ & 2.015 & 1.96 \\
\hline
\end{tabular}




\begin{tabular}{|c|c|c|c|}
\hline $\begin{array}{l}\text { Treatment } \\
\text { (Time, \% Crude oil) }\end{array}$ & $\begin{array}{l}\text { RNA yield } \\
(\mu \mathrm{g} / \mathrm{g} \text { FW) }\end{array}$ & $\mathbf{A}_{260} / \mathbf{A}_{280}$ & $\mathbf{A}_{260} / \mathbf{A}_{230}$ \\
\hline $7^{\text {th }}$ day $+1 \%$ & $1.1^{\mathrm{g}}$ & 1.99 & 1.965 \\
\hline $14^{\text {th }}$ day & $1.615^{\mathrm{f}}$ & 1.96 & 1.99 \\
\hline $14^{\text {th }}$ day+ $0.02 \%$ & $1.681^{\mathrm{e}}$ & 2 & 1.94 \\
\hline $14^{\text {th }}$ day $+1 \%$ & $1.821^{\mathrm{d}}$ & 1.95 & 1.88 \\
\hline $21^{\text {st }}$ day & $1.926^{\mathrm{c}}$ & 1.96 & 1.9 \\
\hline $21^{\text {st }}$ day + $0.02 \%$ & $2.045^{\mathrm{b}}$ & 1.945 & 1.87 \\
\hline $21^{\text {st }}$ day + 1\% & $2.64^{\mathrm{a}}$ & 1.9 & 1.84 \\
\hline
\end{tabular}

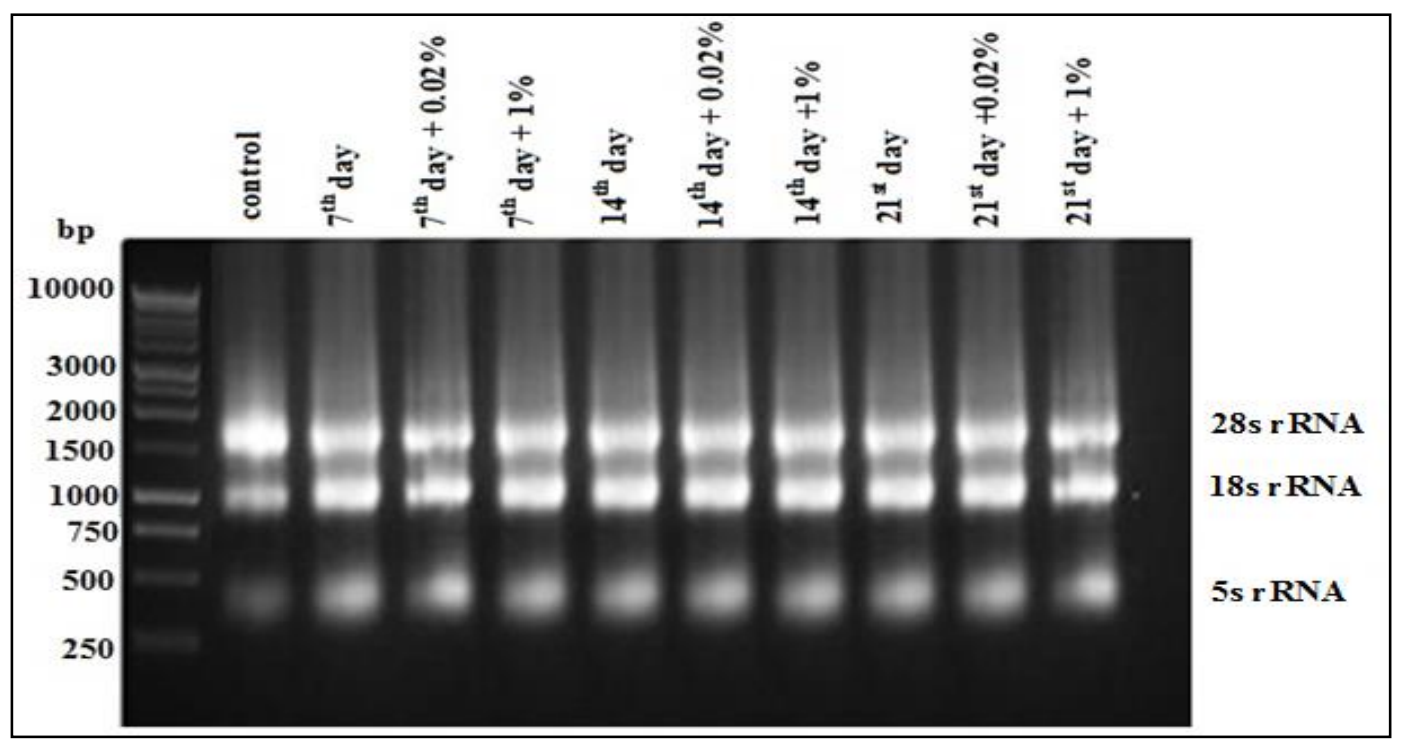

Figure 1. Gel electrophoresis of the total RNA extracted from algal cells.

\subsection{Gene melting curve.}

Light fluorescence intensity was detected to be $91{ }^{\circ} \mathrm{C}$ for the lox gene (Figure 2) and $84{ }^{\circ} \mathrm{C}$ for the 18 srRNA gene, respectively (Figure 3 ). The presence of one peak at the same temperature for all treatments indicated that the primers specifically amplified a specific fragment (84 bp). This result was also confirmed by agarose gel electrophoresis (Figure 5).

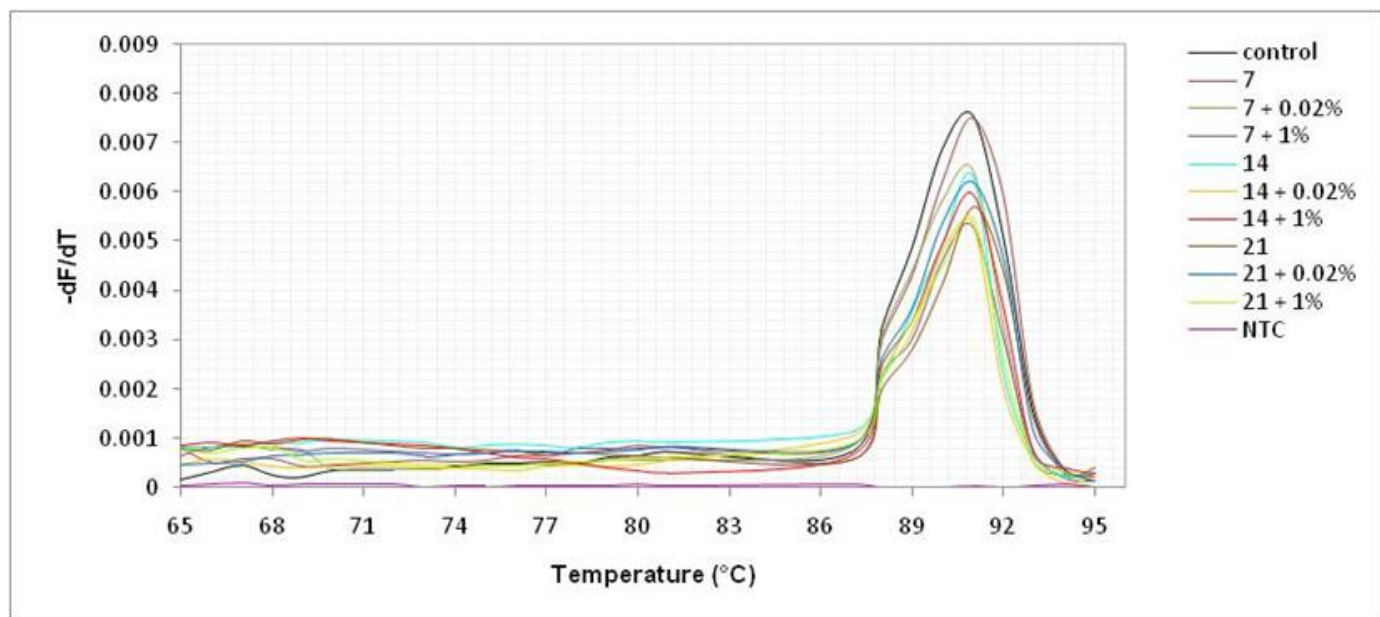

Figure 2. The melting curve of LOX. Sharp peaks and almost the same temperatures for all samples indicated the accuracy and specificity of the designed primers' reaction. 


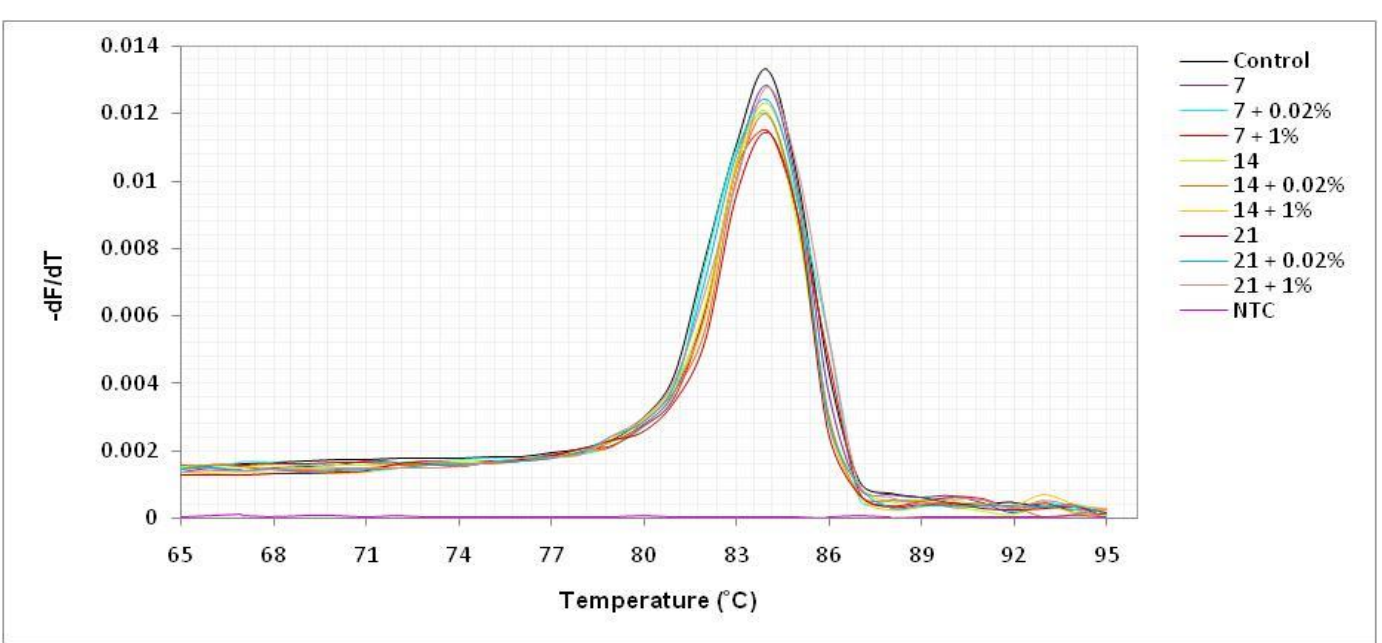

Figure 3. The melting curve of 18srRNA.

\subsection{Gene amplification .}

Cycle threshold (CT) values for lox were established at various crude oil concentrations and incubation periods using the gene amplification curve (Figure 4). An amplification plot was not generated for NTC (Figure 5).

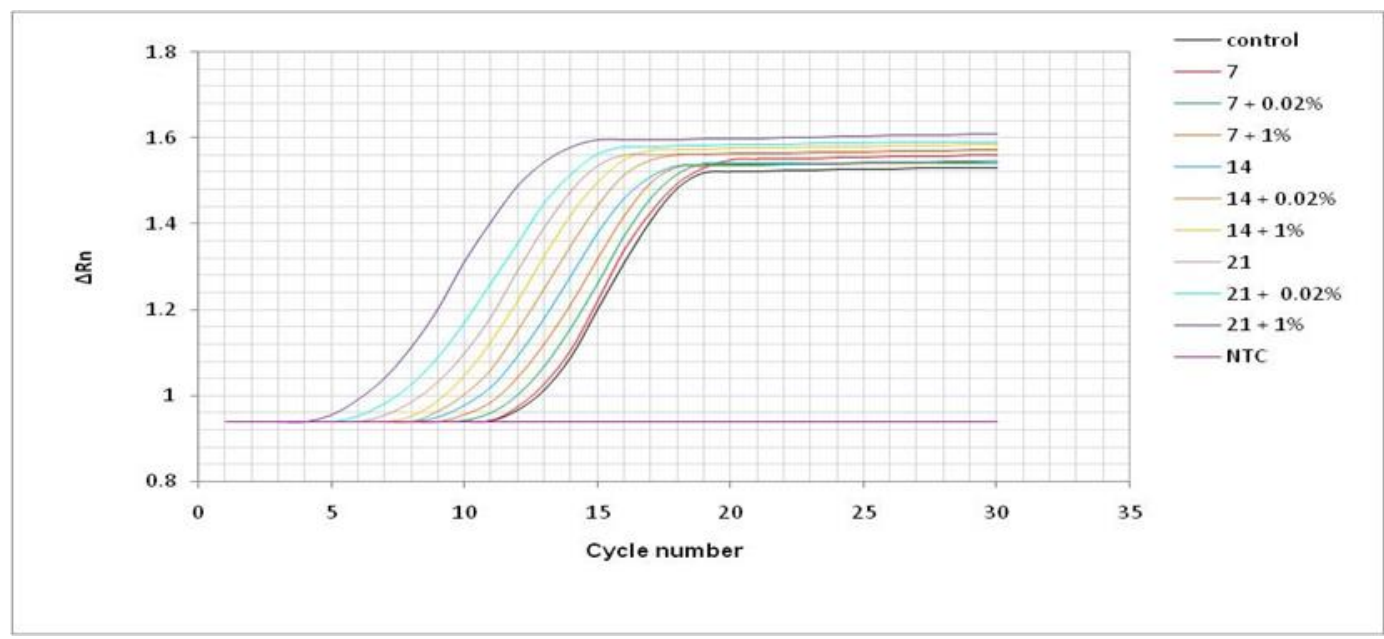

Figure 4. Amplification curve of the lox gene.

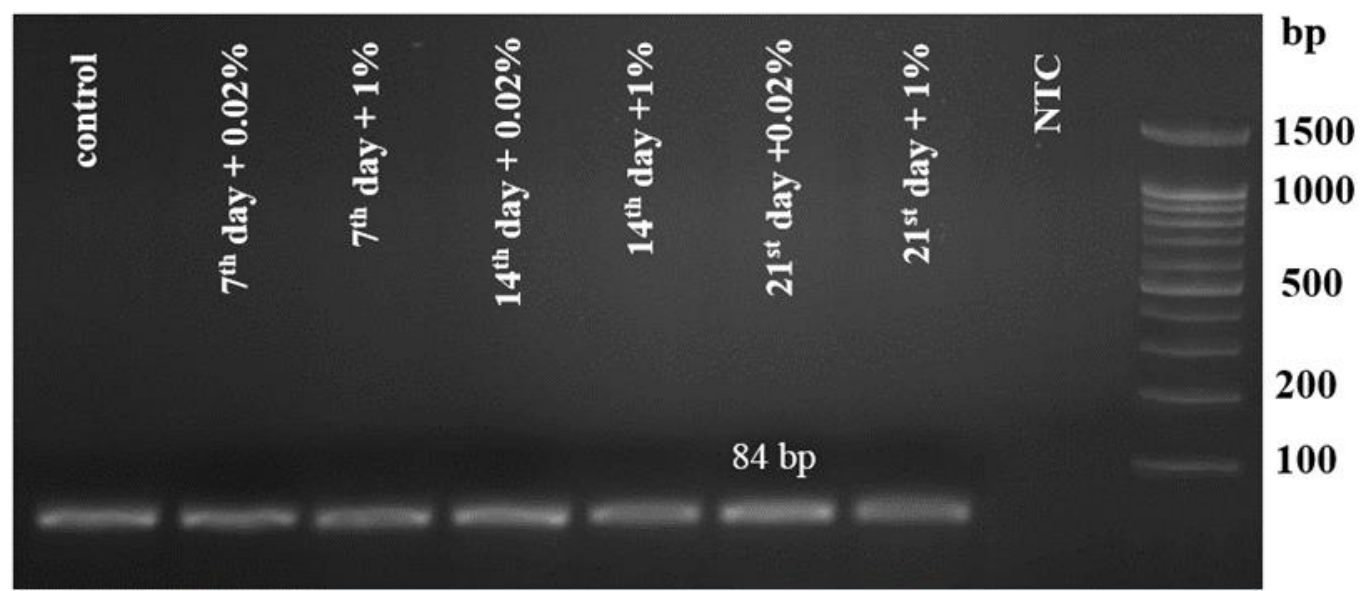

Figure 5. Gel electrophoresis of LOX amplified fragments: NTC (No RT Control). 


\subsection{Relative gene expression.}

According to the results, the expression level of the lox gene was amplified by increasing crude oil concentration (Figure 6). Also, the relative expression of the lox gene was enhanced over a period of time in the treated and control cells, whose highest gene expression level was observed in the presence of $1 \%$ crude oil on the $21^{\text {st }}$ day.

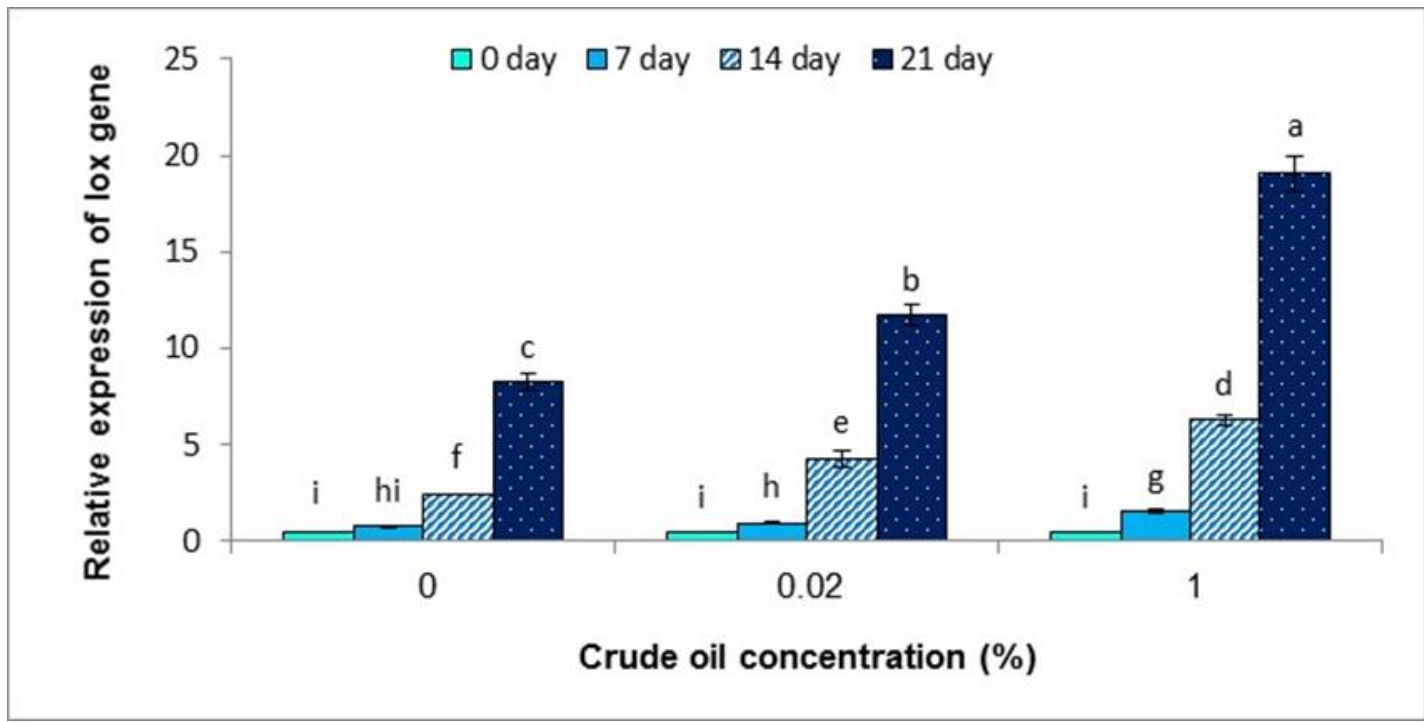

Figure 6. Relative expression of lox gene in S. dimorphus after exposure to different concentrations of crude oil. Error bars displayed the mean \pm SD.

In recent years, it has become obvious that prokaryotic and eukaryotic algae are sources of different phycooxylipins such as fatty acid aldehydes, alcohols, and ketones resulting from LOXs activities. These compounds have diverse physiological functions and play substantial roles in regulating algal cell development [13]. For example, the activation of 15-LOX resulted in the 15-hydroxyeicosatetraenoic acid (15-HETE) production, which promoted the cell cycle [22]. It was also reported that oxylipin generation was increased by the growth progress of the diatom Pseudo-nitzschia delicatissima, and some compounds such as 15-oxoacid were formed only in the stationary phase [23]. Additionally, the increased production of LOX-mediated metabolites such as polyunsaturated aldehydes has been observed during the stationary growth curve of the diatom Skeletonema marinoi by depletion of phosphorus and silica [24]. Also, the expression levels of lox in brown algae Ectocarpus siliculosus was enhanced under hyposaline, hypersaline, oxidative, and copper stresses [10]. It was described that 1-octen-3-ol treatment markedly increased the lox gene expression level in the red alga Pyropia haitanensis [11]. Application of ulvan, a sulfated polysaccharide elicitor obtained from the green algae Ulva spp, induced the lox gene expression and the jasmonate pathway in Medicago truncatula [25].

It seems that LOX enzymes of algae have a close relationship with those in prokaryotes. The sequences of LOX proteins from Nostoc punctiforme ( $N p \mathrm{LOX} 1$ and $N p L O X 2$ ) were analyzed. The results confirmed that they exhibited a considerable homology with the bacterial LOX sequence of Pseudomonas aeruginosa [26]. Many studies have also revealed that algae LOXs were probably related to LOXs of evolutionary ancestors of higher plants and animals $[17,18,27]$.

Unlike LOXs of plants and animals, LOX enzymes in algae contain a single domain [10,27]. Furthermore, LOXs of algae always exhibit nonspecific and multifunctional properties. They have lipoxygenase and hydroperoxidase activities due to their flexible 
catalytic position $[11,18,27]$. Therefore, they can catalyze various polyunsaturated fatty acids. The functional divergence likely occurs since lox genes duplication during different life stages [10].

Based on our findings, the lox expression in microalga was induced under crude oil stress. As a result, the created LOX decomposes hydrocarbons of petroleum and produces hydroperoxy-fatty acids [17,18] and other oxylipins. On the other hand, LOXs probably catalyze crude oil rich in hydrocarbons containing double bonds to produce saturated fatty acids as triglycerides (TGs), which are mainly used to produce biodiesel [28]. There are many documents that $S$. dimorphus may be a proper case for the production of fine quality biodiesel by increasing the concentration of saturated fatty acids and decreasing the PUFA contents under different stresses [29-33].

\section{Conclusions}

The present study assessed the alterations in the expression level of lipoxygenase (lox) gene in the green alga $S$. dimorphus under crude oil contamination. In conclusion, exposure of S. dimorphus to crude oil increased the expression level of the lox gene compared to control cells. Accordingly, S. dimorphus possesses a high enzymatic capacity to deteriorate toxic hydrocarbons and overcome crude oil pollution. Through produced LOX enzyme and following reactions, the algal cells may supply some metabolites such as oxylipins, hydrocarbons, and triglycerides as the substances required for their growth and development and resistance to crude oil stress.

\section{Funding}

This research received no external funding.

\section{Acknowledgments}

The authors are grateful to the University of Tabriz for financial supports.

\section{Conflicts of Interest}

The authors declare no conflict of interest.

\section{References}

1. Diaz-Uribe, C.; Vallejo, W.; Quiñones, C. Physical-chemical study of anthracene selective oxidation by a Fe(III)-phenylporhyrin derivative. Int. J. Mol. Sci. 2020, 21, 1-11, https://doi.org/10.3390/ijms21010353.

2. Takáčová, A.; Smolinská, M.; Ryba, J.; Mackul'ak, T.; Jokrllová, J.; Hronec, P.; Č́́k, G. Biodegradation of Benzo[a]Pyrene through the use of algae. Cent. Eur. J. Chem. 2014, 12, 1133-1143, https://doi.org/10.2478/s11532-014-0567-6.

3. Asghari, S.; Rajabi, F.; Tarrahi, R.; Salehi-Lisar, S.Y.; Asnaashari, S.; Omidi, Y.; Movafeghi, A. Potential of the green microalga Chlorella vulgaris to fight against fluorene contamination: evaluation of antioxidant systems and identification of intermediate biodegradation compounds. J. Appl. Phycol. 2020, 32, 411-419, https://doi.org/10.1007/s10811-019-01921-7.

4. Dhar, K.; Subashchandrabose, S.R.; Venkateswarlu, K.; Krishnan, K.; Megharaj, M. Anaerobic microbial degradation of polycyclic aromatic hydrocarbons: a comprehensive review. Rev. Environ. Contam. Toxicol. 2020, 251, 25-108, https://doi.org/10.1007/398_2019_29.

5. Sakshi; H.A.K. A comprehensive review of metabolic and genomic aspects of PAH degradation. Arch. Microbiol. 2020, 202, 2033-2058, https://doi.org/10.1007/s00203-020-01929-5.

6. Ghosal, D.; Ghosh, S.; Dutta, T.K.; Ahn, Y. Current state of knowledge in microbial degradation of polycyclic aromatic hydrocarbons (PAHs): a review. Front. Microbiol. 2016, 7, 1-27, https://doi.org/10.3389/fmicb.2016.01369. 
7. Xaaldi Kalhor, A.; Movafeghi, A.; Mohammadi-Nassab, A.D.; Abedi, E.; Bahrami, A. Potential of the green alga Chlorella vulgaris for biodegradation of crude oil hydrocarbons. Mar. Pollut. Bull. 2017, 123, 286-290, http://dx.doi.org/10.1016/j.marpolbul.2017.08.045.

8. Takáčová, A.; Smolinská, M.; Semerád, M.; Matúš, P. Degradation of BTEX by microalgae Parachlorella kessleri. Pet. Coal 2015, 57, 101-107.

9. Barati, B.; Gan, S.Y.; Lim, P.E.; Beardall, J.; Phang, S.M. Green algal molecular responses to temperature stress. Acta Physiol. Plant. 2019, 41, 1-19, https://doi.org/10.1007/s11738-019-2813-1.

10. Teng, L.; Han, W.; Fan, X.; Xu, D.; Zhang, X.; Dittami, S.M.; Ye, N. Evolution and expansion of the prokaryote-like lipoxygenase family in the brown alga Saccharina japonica. Front. Plant Sci. 2018, 8, 1-15, https://doi.org/10.3389/fpls.2017.02018.

11. Chen, H.; Yang, R.; Chen, J.; Luo, Q.; Cui, X.; Yan, X.; Gerwick, W.H. 1-Octen-3-ol, a self-stimulating oxylipin messenger, can prime and induce defense of marine alga. BMC Plant Biol. 2019, 19, 1-16, https://doi.org/10.1186/s12870-019-1642-0.

12. Barbosa, M.; Valentão, P.; Andrade, P.B. Biologically active oxylipins from enzymatic and nonenzymatic routes in macroalgae. Mar. Drugs 2016, 14, 1-26, https://doi.org/10.3390/md1401002326805855.

13. Esposito, R.; Ruocco, N.; Albarano, L.; Ianora, A.; Manfra, L.; Libralato, G.; Costantini, M. Combined effects of diatom-derived oxylipins on the sea urchin Paracentrotus lividus. Int. J. Mol. Sci. 2020, 21, 1-14, https://doi.org/10.3390/ijms21030719.

14. Ruocco, N.; Nuzzo, G.; d’Ippolito, G.; Manzo, E.; Sardo, A.; Ianora, A.; Romano, G.; Iuliano, A.; Zupo, V.; Costantini, M.; Fontana, A. Lipoxygenase pathways in diatoms: occurrence and correlation with grazer toxicity in four benthic species. Mar. Drugs 2020, 18, 1-14, https://doi.org/10.3390/md18010066.

15. Russo, E.; d'Ippolito, G.; Fontana, A.; Sarno, D.; D’Alelio, D.; Busseni, G.; Ianora, A.; Elert, E.; Carotenuto, Y. Density-dependent oxylipin production in natural diatom communities: possible implications for plankton dynamics. The ISME J. 2020, 14, 164-177, https://doi.org/10.1038/s41396-019-0518-5.

16. Lauritano, C.; Luca, D.D.; Amoroso, M.; Benfatto, S.; Maestri, S.; Racioppi, C.; Esposito, F.; Ianora, A. New molecular insights on the response of the green alga Tetraselmis suecica to nitrogen starvation. Sci. Rep. 2019, 9, 1-12, https://doi.org/10.1038/s41598-019-39860-5.

17. Djian, B.; Hornung, E.; Ischebeck, T.; Feussner, I. The green microalga Lobosphaera incisa harbours an arachidonate 15S-lipoxygenase. Plant Biol. 2019, 1, 131-142, https://doi.org/10.1111/plb.12920.

18. Zhu, Z.; Qian, F.; Yang, R.; Chen, J.; Luo, Q.; Chen, H.; Yan, X. A Lipoxygenase from red alga Pyropia haitanensis, a unique enzyme catalyzing the free radical reactions of polyunsaturated fatty acids with triple ethylenic bonds. PLOS ONE 2015, 10, 1-20, https://doi.org/10.1371/journal.pone.0117351.

19. Xaaldi Kalhor, A.; Mohammadi-Nassab, A.D.; Abedi, E.; Bahrami, A.; Movafeghi, A. Biodiesel production in crude oil contaminated environment using Chlorella vulgaris. Bioresour. Technol. 2016, 222, 190-194, http://dx.doi.org/10.1016/j.biortech.2016.09.110.

20. Li, X.; Cai, F.; Luan, T.; Lin, L.; Chen, B. Pyrene metabolites by bacterium enhancing cell division of green alga Selenastrum capricornutum. Sci. Tot. Environ. 2019, 689, 287-294, https://doi.org/10.1016/j.scitotenv.2019.06.162.

21. Luo, J.; Deng, J.; Cui, L.; Chang, P.; Dai, X.; Yang, C.; Li, N.; Ren, Z.; Zhang, X. The potential assessment of green alga Chlamydomonas reinhardtii CC-503 in the biodegradation of benz(a)anthracene and the related mechanism analysis. Chemosphere 2020, 249, 1-44, https://doi.org/10.1016/j.chemosphere.2020.126097.

22. Li, Y.; Zhang, L.; Wang, X.; Chen, M.; Liu, Y.; Xing, Y.; Wang, X.; Gao, S.; Zhu, D. Elk-1-mediated 15lipoxygenase expression is required for hypoxia-induced pulmonary vascular adventitial fibroblast dynamics. Acta Physiol. 2016, 218, 276-289.

23. d'Ippolito, G.; Lamari, N.; Montresor, M.; Romano, G.; Cutignano, A.; Gerecht, A.; Cimino, G.; Fontana, A. 15S-Lipoxygenase metabolism in the marine diatom Pseudo-nitzschia delicatissima. New Phytologist 2009, 183, 1064-1071.

24. Ribalet, F.; Wichard, T.; Pohnert, G.; Ianora, A.; Miralto, A.; Casotti, R. Age and nutrient limitation enhance polyunsaturated aldehyde production in marine diatoms. Phytochemistry 2007, 68, 2059-2067, https://doi.org/10.1016/j.phytochem.2007.05.012.

25. Jaulneau, V.; Lafitte, C.; Jacquet, C.; Fournier, S.; Salamagne, S.; Briand, X.; Esquerr'e-Tugay’e, M.T.; Dumas, B. Ulvan, a sulfated polysaccharide from green algae, activates plant immunity through the jasmonic acid signaling pathway. J. Biomed. Biotech. 2010, 2010, 1-11, https://doi.org/10.1155/2010/525291.

26. Koeduka, T.; Kajiwara, T.; Matsui, K. Cloning of lipoxygenase genes from a cyanobacterium, Nostoc punctiforme, and its expression in Eschelichia coli. Curr. Microbiol. 2007, 54, 315-319, https://doi.org/10.1007/s00284-006-0512-9.

27. Chen, H.; Zhu, Z.; Chen, J.; Yang, R.; Luo, Q.; Xu, J.; Shan, H.; Yan, X. A multifunctional lipoxygenase from Pyropia haitanensis - The cloned and functioned complex eukaryotic algae oxylipin pathway enzyme. Algal Res. 2015, 12, 316-327, http://dx.doi.org/10.1016/j.algal.2015.09.015.

28. Vingiani, G.M.; Luca, P.D.; Ianora, A.; Dobson, A.D.W.; Lauritano, C. Microalgal enzymes with biotechnological applications. Mar. Drugs 2019, 17, 2-20, https://doi.org/10.3390/md17080459. 
29. Vadivel, M.; Arvindnarayan, S.; Kumar, G.; Shobana, S.; Dharmaraja, J.; Nguyen, D.D.; Chang, S.W.; Prabhu, K.K.S. Biodiesel potentiality of microalgae species: evaluation using various nitrogen sources. Waste Biomass Valorization 2019, 11, 1671-1679, https://doi.org/10.1007/s12649-018-00552-2.

30. Mediboyina, M.K.; Banuvalli, B.K.; Chauhan, V.S.; Mudliar, S.N. Comparative life cycle assessment of autotrophic cultivation of Scenedesmus dimorphus in raceway pond coupled to biodiesel and biogas production. Bioprocess Biosyst. Eng. 2020, 43, 233-247, https://doi.org/10.1007/s00449-019-02220-8.

31. Ravindran, B.; Kassim, M.A.; Mohamed, M.S. Screening of medium constituents for the cultivation of Scenedesmus dimorphus UTEX 1237 using 2k factorial design approach. Mater. Sci. Eng. 2020, 716, 1-9, https://doi.org/10.1088/1757-899X/716/1/012003.

32. Kabir, F.; Gulfraz, M.; Raja, G.K.; Inam-ul-Haq, M.; Awais, M.; Mustafa, M.S.; Khan, S.U.; Tlili, I.; Shadloo, M.S. Screening of native hyper-lipid producing microalgae strains forbiomass and lipid production. Renew. Energy 2020, 160, 1295-1307, https://doi.org/10.1016/j.renene.2020.07.004.

33. Gour, R.S.; Garlapati, V.K.; Kant, A. Effect of salinity stress on lipid accumulation in scenedesmus sp. and chlorella sp.: feasibility of stepwise culturing. Curr. Microbiol. 2020, 77, 779-785, https://doi.org/10.1007/s00284-019-01860-z. 